\title{
Azərbaycanda Proqram Mühəndisliyinin Tədrisinin Müasir Vəziyyəti
}

\author{
Almaz Oliyeva \\ Mingəçevir Dövlət Universiteti, Mingəçevir, Azərbaycan \\ almaz40@gmail.com
}

\begin{abstract}
Xülasə- Məqalədə proqram muhəndisliyinin inkişaf, Azərbaycanda proqram muhəndisliyinin tədrisinin hazırkı vəziyyəti araşdırılmış vo muasir standartlara cavab verən mutəxəssislərin hazırlanmasının vacibliyi qeyd olunmuşdur. Proqram muhəndisliyinin tədrisində movcud olan problemlərin aradan qaldırılması ucun tovsiyələr verilmişdir.
\end{abstract}

Açar sözlor- proqram muhondisliyi, proqram sistemlori, todris standartları, biliklor comiyyati

\section{GİRİŞ}

Hər bir dövlətin gələcəyi onun təhsil sistemindən asılıdır. Təhsil hər bir suveren dövlətin strateji əhəmiyyətli fəaliyyət sahəsi olub, onun siyasi-iqtisadi, sosial və mədəni inkişafını müəyyən edir və yeni qurulmuş cəmiyyətin mənəvi dəyərlərinin formalaşmasında böyük rol oynayır.

Azərbaycan Respublikasının dövlət siyasətində təhsilin təşkili prinsipləri, onun səviyyəsi, keyfiyyəti nəzərdə tutulmuşdur. Ali təhsil müəssisələrində təhsil alanlara verilən bilik səviyyəsi onların gələcək fəaliyyətlərinə təsir edir. Hər bir təhsil növü təhsilin səviyyəsindən asılı olmayaraq müəyyən proqram üzrə həyata keçirilir. Tədris prosesinin keyfiyyətini yüksəltmək üçün elm və texnologiyanın müasir nailiyyətlərini təhsil sisteminə tətbiq etmək lazımdır. $\mathrm{Bu}$ gün elm və texnikanın dinamik inkişaf edən sahələrindən biri də informasiya-kommunikasiya texnologiyalarıdır (IKKT). Hazırda dünyada istehsalın bütün sahələrində informasiyakommunikasiya texnologiyalarından istifadə edilir. İnformasiya cəmiyyətinin qurulmasında, insanların həyat səviyyəsinin yüksəlməsində, yeni iş yerlərinin açılmasında, insan əməyinin yüngülləşməsində İKT-nin rolu böyükdür.

Azərbaycanda internet istifadəçilərinin sayı gündən-günə artır. Tələbələrin İKT biliklərinin artırılması üçün bütün ali təhsil müəssisələri internetə qoşulmuşdur. Tələbə internet xidmətindən istifadə imkanına malik olarsa, onun qarşısında zəngin biliklər dünyası açılmış olur.

Ali təhsil pilləsində cəmiyyətin və əmək bazarının tələbatı nəzərə alınmaqla yüksək ixtisaslı mütəxəssislərin və elmipedaqoji kadrların hazırlığı həyata keçirilir. Bunun üçün ilk növbədə təhsil müəssisələrinin texniki vasitələrlə təminatını yaxşılaşdırmaq, tədrisə yüksək ixtisaslı və təcrübi vərdişlərə malik mütəxəssisləri cəlb etmək lazımdır. Biliklər iqtisadiyyatının formalaşmasında vacib istiqamətlərdən olan proqram mühəndisliyi də yeni bir fənn kimi formalaşmalı və tədris edilməlidir.

\section{PROQRAM MÜHONDISLIYINININ İNKIŞAF MORHOLӘLӘRİ}

"Proqram mühəndisliyi (PM)" (software engineering) termini ilk dəfə 1968-ci ildə NATO-nun proqram təminat böhranına həsr edilmiş konfransında meydana gəlmişdir. $\mathrm{O}$ vaxtdan indiyədək PM tədqiqat oblastı kimi böyüyüb inkişaf etmişdir və keyfiyyətli proqram təminatının yaradılmasına xidmət edir. Proqram təminatının işlənilməsi informatika, layihənin idarə olunması və sistem mühəndisliyi fənləri ilə s1x əlaqəlidir.

Proqram muhəndisliyi - sistemləşdirilmiş standartlar qrupundan istifadə etməklə proqram vasitələri və komplekslərinin işlənilməsi, praktiki tətbiqi, muşayiət edilməsi və təkmilləşdirilməsini təmin edən elm sahəsidir. [1]; $\mathrm{Bu}$ fənn proqram sisteminin həyat dövrünün bütün mərhələlərini: proqrama tələbatların analizi, proqramların spesifik xüsusiyyətləri, layihələndirmə, işlənilmə, testləmə, tətbiqi və müşayiət edilməsini əhatə edir.

Ümumilikdə PM keyfiyyətli proqram təminatı yaratmaq üçün nəzərdə tutulmuş metodlar, vasitələr və üsullar toplusudur. Başqa sözlə, proqram mühəndisliyi məsələnin həlli üçün istifadə edilən proqram təminatının işlənilməsi, istifadəsi üçün sistemləşdirilmiş metodlara malik elm sahəsidir [2].

İlk dəfə 1990-c1 illərin sonunda proqram mühəndisliyi sahəsində dünya lideri olan ABŞ-ın Massaçusets Texnologiya İnstitutunda alimlərin, tələbələrin, sənaye nümayəndələrinin iştirakı ilə proqram mühəndisliyinə hazırlıq məqsədilə konseptual təşəbbüs CDIO (Conceive, Design, Implement, Operate) qəbul edilmişdir. Nəzərdə tutulur ki, yeni sistem və texniki obyektlərin yaradılması üçün proqram mühəndisi hazırlığı çərçivəsində hazırlanmış universitet məzunları "təsəvvür-layihə-həyata keçirmək-istismar" vəziyyətində olmalı, bu proseslərdə əmrlər əsasında hərəkət etməlidirlər. Bu təşəbbüs təcrübə yönümlü proqram mühəndisliyi konsepsiyası hesab edilir [3].

1993-cü ildə İEEE Computer Society və ACM peşəkar cəmiyyətləri proqram mühəndisliyinin müstəqil bir peşə kimi təşəkkül tapması üçün fəaliyyətin qiymətləndirilməsi, planlaşdırılması və uyğunlaşdırılmasının zəruriliyi məqsədi ilə birləşmiş komitə yaratdılar. Komitənin əsas vəzifəsi PM sahəsində biliklər toplusunun formal yazılışını vermək, həmin ixtisas üçün dərslik proqramlarını formalaşdırmaq, uyğun sahə üçün tələbləri təyin etməkdən ibarət idi [4]. 
Qeyd etmək lazımdır ki, ötən illər ərzində proqram təminatı işləyib hazırlayan, yəni proqram istehsalı ilə məşğul olan mütəxəssislər bəzi praktiki layihələrdə effektivliyi təsdiq edilmiş proqramların təkmilləşdirilməsi metodlarının prinsiplərini işləyib hazırlamışlar. Bunlara proqram təminatının işlənib hazırlanması metodları, struktur və obyektyönümlü proqramlaşdırma, proqram proseslərinin təkmilləşdirilməsi modeli, proqram təminatının işlənib hazırlanmasının avtomatlaşdırılması vasitələri və 4-cü nəsil proqramlaşdırma dillərini aid etmək olar. Buna baxmayaraq, keyfiyyətli proqram təminatının işlənməsi problemləri həll edilməmişdir [5].

\section{AZӘRBAYCANDA PROQRAM MÜHONDISLIYYININ TODRISIININ MÜASİR VӘZIYYYTİ}

Azərbaycanda proqramlaşdırma 60-cı illərdən başlayaraq geniş istifadə edilməyə başlanmışdır. Azərbaycanın Avropaya inteqrasiyasından sonra bu sahədə işlər daha da gücləndirilmişdir. Təhsilin informasiyalaşması məqsədyönlü, xüsusi təşkil edilmiş, mükəmməl layihələndirilmiş prosesdir. Təhsilin informasiyalaşması - təhsilin keyfiyyətini yüksəltmək üçün İKT-nin intensiv tətbiqinə yönəlmiş tədbirlər külliyyatıdır. Təhsilin informatlaşması təhsildə real vəziyyətin dəyişməsinə, təhsilin məzmun, forma və texnoloji baxımdan təkmilləşməsinə xidmət edib pedaqoji innovasiyaların nüvəsi hesab edilir. Təhsildə İKT-nin tətbiqinin pedaqoji səmərə verməsi, keyfiyyətin yüksəlməsinə xidmət etməsi üçün prosesin elmi cəhətdən tədqiqi əhəmiyyətlidir. Müasir dövrdə tədris edilən dərslər ənənəvi dərslərdən fərqlənməlidir.Yəni dərsin formasının müxtəlifliyi təmin edilməli, öyrənilən hər mövzu əyani vəsaitlə təmin edilməli, multimediya materiallarından istifadə edilməlidir. Lazımı vəsaitlərdən istifadə etdikdə təhsil alanın müstəqillik, işgüzarlıq, təfəkkür fəallığı, yaradıcılıq, məsuliyyət kimi keyfiyyətləri üzə çıxır və formalaşır. Başqa məkanların verilənlər bazasından əldə olunmuş materiallar ilə dərsi təmin etmək mümkün olur, virtual məkanın imkanlarından istifadə etməklə müəllimlər öz bacarıqlarını təkmilləşdirir, biliklərini yeniləşdirir, vaxta qənaət edirlər.

Hazırda PM üzrə yeni nəsil mütəxəssislərin hazırlanması yaranmış problemlərin aradan qaldırılması vasitələrindən biri hesab edilə bilər. PM üzrə ayrıca ixtisas yaratmaq zəruri olard1. PM sahəsində yeni tədris proqramlarının həyata keçirilməsi ali məktəbin nüfuzunu qaldıra bilər. Bu sahə üzrə mütəxəssislərin hazırlanması fundamental texniki təhsilin istiqaməti hesab edilir. İnformatikanın, riyaziyyatın, digər baza elmlərinin öyrənilməsi əsasında tədqiqatın əks olunduğu, konstruktor-təcrübə işlərinin, sənayenin texnoloji hazırlığı onun əsasını təşkil edir. Mütəxəssislərin fikrincə informatika ixtisası üzrə proqramların olması PM-in formalaşmasında vacib rol oynayır. Bunun üçün resursların və professormüəllim heyətinin kifayət qədər biliklərə malik olması zoruridir.

Ali məktəblər PM-in geniş yayılmasını yalnız proqramçı hazırlamaqda görməməlidirlər. Ali məktəblərdə bu sahə üzrə kurslar təşkil etməlidir. Yeni ixtisasın keçirilməsinə marağ 1 olan hər bir tədris müəssisəsi bu sahəyə olan tələbləri, tələbələrin potensial mühitini və müəllimlərin həmin ixtisas üzrə lazımı qədər biliyə malik olduğunu təyin etməlidir.
"Proqram mühəndisliyi" ixtisası tədris olunan fakültələrdə fənlərarası inteqrasiyadan istifadə etmək lazımdır. $\mathrm{Bu}$ inteqrasiyanı təşkil etmək üçün müəllimlərə həmin fənlər üzrə tədris müəssisəsinin eyni bölməsində iş aparmağa şərait yaratmaq lazımdır.

"İnformatika" ixtisası üzrə buraxılan mütəxəssislərin sayını azaltmadan proqram təminatı üzrə daha ixtisaslı mütəxəssislərin artmasına imkan yarana bilər. "Proqram mühəndisliyi" ixtisasını səmərəli təqdim etmək üçün informatika sahəsinin nəzəri əsaslarını verməklə yanaşı, yeni proqramda bu sahəyə ənənəvi mühəndis yanaşması da təmin olunmalidir.

Proqram mühəndisliyi sahəsində təhsil alan tələbə təcrübi çalışma kurslarnı yalnız tədris vaxtı deyil, həm də layihələndirmə və işlənilmə prosesində vacib vəzifələrin həlli üçün işə qəbul olunan zaman və vəzifəyə təyin olunandan əvvəldə keçməlidirlər. Bu cür yanaşma yalnız mühəndislik fənninə deyil, həmçinin bütün digər fənlərə də aid olmalıdır.

Bundan başqa, proqram mühəndislərinin işə münüsibəti də dəyişilməlidir. Proqram mühəndisliyi üzrə müasir yeniliklərlə ayaqlaşmaq üçün mütəxəssislər informatika və proqram mühəndisliyi sahəsində aldıqları təhsili qiymətləndirməli, ona çox böyük məsuliyyətlə yanaşmalı, bu sahədə öz ixtisasını artırmalı və biliklər bazasına malik olmalıdirlar. Oks halda proqram mühəndisliyi ixtisası alan gənc mütəxəsislər öz bilik bazalarını artırmağı bacarmazlar və nəticədə düzgün olmayan iş metodundan istifadə etməyə məcbur olarlar.

"Proqram mühəndisliyi" ixtisasının dərslik proqramına adi yanaşmaq, həmin proqramları yaratmaq, təklif etmək və dərindən dərk etməklə hansı təhsil modelinin daha münasib olmasını təyin etmək mümkün olar. Bununla bərabər tədris kurslarında bu sahənin maraqlarını da nəzərə almaq zəruridir. Ancaq bu halda proqram mühəndisliyi bir ixtisas kimi status almış olar.

Qabaqc1l proqram sənayesinə malik olan olkələrin universitetlərində proqram muhəndisliyinin və informatikanın tədrisi ucun aşağıda gostərilən vəsaitlərdən istifadə edilir:

1. Computing Curriculum (hesablama texnikası uzrə kurrikulum) layihəsi cərcivəsində Elektronika və Elektrotexnika uzrə muhəndislər institutu (IEEE - Institute of Electrical and Electronics Engineers) vo Hesablama Texnikası Assosiasiyası (ACM - Association for Computing Machinery) proqram muhəndisliyinin universitetlərdə tədrisinə dair tovsiyyələrdən ibarət olan SE2014 (Software Engineering 2014: Curriculum Guidelines for Undergraduate Degree Programs in Software Engineering - Proqram muhəndisliyi 2014: bakalavrlar ucun proqram muhəndisliyi sahəsi uzrə tədris proqramı) sənədini işləmişlər. SE2014 universitet və kolleclərin proqram muhəndisliyi uzrə tədris etməli olduqları bilikləri ayrılıqları ilə təsvir edir, tədrisin umumi prinsiplərini gostərir. Bu sənəddə tədris planlarının numunələri də verilmişdir ;

2. Proqram Muhəndisliyinin koordinasiya komitəsi (Software Engineering Coordinating Committee) tərəfindən proqram muhəndisliyi uzrə biliklər toplusu - SWEEBOK (Software Engineering Body of Knowledge) işlənilmişdir. 2013-cü ildə işlənilmiş son versiyası 15 bilik sahəsini əhatə 
edir. (SWEEBOK V3) ISO/IEC TR 19759:2005 standartına əsaslanır və uzun illər işləmiş peşəkar mütəxəssilərin bilikləri əsasında hazırlanmışdır;

3. 2009-cu ildə Sistem mühəndisliyi üzrə beynəlxalq şura INCOSE (International Council on Systems Engineering), $I E E E, A C M$ və başqalarının iştirakı ilə proqram mühəndisliyi üzrə magistr hazırlığı üçün kurrikulum GswE2009 (Graduate Software Engineering 2009) işlənilmişdir;

4. ACM, IEEE vo IEEE Computer Society (IEEE kompyüter cəmiyyəti) iştirakı ilə Computing Curricula 2013: Computer Science (Hesablama texnikası üzrə kurrikulum 2013: Kompyüter elmləri) informatika və proqram mühəndisliyi üzrə tədris standartının son versiyası işlənilmişdir [6].

Ali məktəblərdə proqram mühəndisliyinin tədrisini bu sahə üzrə qabaqcil dövlətlər səviyyəsinə qaldırmaq üçün tələbələrə proqram mühəndisliyinin əsasları, proqram təminatının müasir işlənilmə texnologiyaları və metodları, proqramların işlənilməsi, konfiqurasiyanın idarə edilməsi kimi biliklər öyrədilməlidir.

Son zamanlar respublikamızda hər il şagirdlər və tələbələr arasında informatika olimpiadalarının keçirilməsi yeniyetmə və gənclər arasında proqramlaşdırmaya marağın artması baxımından mühüm əhəmiyyət kəsb edir. Artıq azərbaycanlı gənc proqramçılar dünyanın aparıcı şirkətlərində işləməyə başlayıblar.

2019-cu ildə Bakıda keçiriləcək Beynəlxalq İnformatika Olimpiadasında qabaqcıl ölkələrlə birlikdə qaliblər sırasında olmaq üçün səmərəli məşğul olmaq lazımdır.

\section{NӘTİCӘ}

Sonda belə bir nəticəyə gəlmək olar ki, informasiya komminikasiya texnologiyalarından istifadə etmədən idarəetməni, təhsilin, istehsalatın səviyyəsini yüksəltmək mümkün deyil. Cəmiyyətin İKT ehtiyaclarının ödənilməsi məqsədlə 2012-ci ilin martında Rabitə və İnformasiya Texnologiyaları Nazirliyinin (indiki Rabitə və Yüksək Texnologiyalar Nazirliyinin - RYTN) tabeliyindo İnformasiya Texnologiyalarının İnkişafı Dövlət Fondu (İTIDF) yaradılıb.
Dəqiq elmlərin tədrisində zəruri olan iri həcmli hesablamaların kompüterləşdirməsinə ehtiyac gündən-günə artır. Təhsil elə təşkil olunmalıdır ki, hər bir təhsil alan elm və texnikanın son nailiyyətlərindən istifadə etməklə informasiya mədəniyyətinə nail olmalı, formalaşmaqda olan informasiya cəmiyyətinin aktiv üzvi kimi fasiləsiz təhsil sistemi əhatəsində "bilik və intellekt" istehsal edə bilsin.

Proqram mühəndisliyi üzrə təhsil dövlətin iqtisadi inkişafinda açar rolunu oynayır. Bunun üçün tələbələrə nəzəri bilikləri öyrətməklə yanaşı, həm alqoritmlərin tərtibi, onların kompüterdə reallaşdırılmasını təşkil etmək lazımdır. Tələbələrin bu biliklərə yiyələnməsi üçün ilk növbədə bu sahələr üzrə dərsliklər hazırlanmalı, beynəlxalq standartlara əsaslanaraq dövlət standartları və tədris planları işlənilməlidir.

\section{ӘDӘBIYYYAT}

[1] T.H. Kazımov, T.A. Bayramova, Proqram mühəndisliyi. Bakı: İnformasiya texnologiyaları, 2013, $188 \mathrm{~s}$.

[2] Ş.Mahmudova., K.Məmtiyev, Proqramlaşdırma və onun inkişaf mərhələləri. Bak1, 2011, $85 \mathrm{~s}$.

[3] К.Ф.Кубрушко, А.М.Любителев, Л.И.Назарова., Е.С.Кулюкина, Формирование компетенций студентов технических профилей с учетом международных стандартов: научно-информационный материал. М.: МГАУ им. В.П. Горячкина, 2011, 54 с.

[4] К. К. Колин, Социальные аспекты информатизации образования // Информационные технологии, № 3. с. 40-50. 2003

[5] В.В. Липаев, Программная инженерия. Методологические основы. Учебник-Москва: Теис, 2006

[6] T.H. Kazımov, T.A. Bayramova, Azərbaycanda proqram mühəndisliyinin tədrisinin problemləri // İnformasiya cəmiyyəti problemləri, 2017, №1, 105-111s. 